1940 , followed by a fall of about $0.3^{\circ} \mathrm{C}$ to the present day - the variations between individual years have often been very much greater. What is known of the influence of these variations, not only of temperature but also of rainfall, on metabolism of organisms, including their growth, development and reproduction, on availability of food, on dispersal and on competition is then discussed in Chapters 6-11.

The style of the book is essentially that of a review. Numerous examples are described but analysis of cause tends to be superficial. There are occasional lapses in which correlation is confused with cause, as, for instance, in the discussion of the relation of flowering of beech (Fagus silvatica) to temperature in June and July of the previous year. The source of this information is also omitted but must surely be the work of Professor J.D. Matthews (Forestry 28, 107-116; 1955).

It is no criticism of the author that so many of the examples to which he refers are little more than simple observations and lack convincing explanations. If the book stimulates biologists to make experimental studies of even a few of the phenomena it describes, it will have done a valuable service to biogeography.

C.D. Pigott is a Professor in the Department of Biological Sciences at the University of Lancaster.

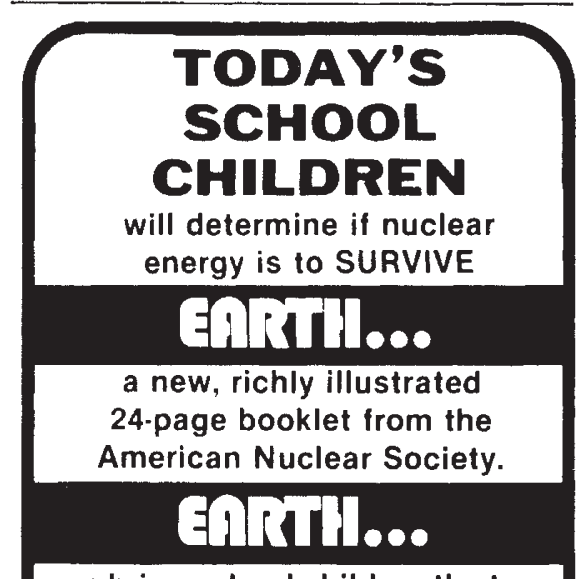

can bring school children the true story of nuclear energy in today's environmentally-oriented society.

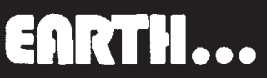

is available in quantity, at a low

cost, to your company for

distribution to eighth and ninth grade students.

Write today for a price schedule and sample copy.

Public

Communications Dept. P

American Nuclear Society

555 N. Kensington Avenue La Grange Park, IL 60525

Circle No.01 on Reader Service Card.

\title{
Protein structure: beyond pretty pictures
}

\section{Nicholas G. Wrigley}

Electron Microscopy of Proteins, Vols 1 and 2. Edited by James R. Harris. Vol. 1, pp.352, ISBN 0-12-327601-2; Vol.2, pp.316, ISBN 0-12-327602-0. (Academic: 1981.) Vol. $1 £ 35$, \$72; Vol. $2 £ 30, \$ 61.50$.

PRACTITIONERS of electron microscopy lie on a spectrum of widely different philosophy. On one hand there are those to whom the technique is entirely incidental to the subject studied, and seems to command no real interest or understanding; such people adduce a mass of poorly understood and suspect EM data to support existing ideas on function or merely to describe structure. On the other hand there are those to whom the technique is all; they produce superb data but without sufficient knowledge of the subject studied to make proper use of them.

This is probably in the nature of science itself, and it is no fault of the editor of Electron Microscopy of Proteins that both these extremes are represented in the first two volumes of this new series. On the contrary it is very much to his credit that he has been able to include much of the middle ground also in these first 14 articles. To this extent his aim ". . . to review the progress achieved in the electron microscopic study of soluble, fibrous and membranebound proteins" has succeeded.

The series is ambitious in its sheer breadth of subject; it could be re-titled Biological Electron Microscopy since virtually all of biology is concerned with proteins at some level. Apparently because of the problems of extracting promised chapters from authors, there is little ordering of this breadth into sub-topics such as soluble, fibrous or membranebound proteins. A reader interested in fibrous proteins must buy Vol. 1 for "Intermediate Filaments", Vol. 2 for "Fibrous Proteins of Connective Tissue", and must await Vol.3 for "Tubulin and Associated Proteins" and eventually Vol.4 for "Muscle Proteins". Since the series is not about EM techniques - though some articles include substantial technical sections - such subdivision would have been desirable and is to be hoped for in any extension of the series.

Electron microscopy of biological systems can only be justified if the aim is to understand function through structure, rather than merely to catalogue structural details. On this criterion some of the studies have no place in these volumes, notwithstanding elegant microscopy. On other grounds this very elegance justifies their presence, though a more critical appraisal of their contribution in understanding function would have helped the general reader. $\mathrm{He}$ can thus be misled into the impression that a welter of beautiful pictures is synonymous with profound functional understanding. However the general high standing and quality of the authorship of these chapters allows the discerning reader to decide for himself which is which. Moreover each chapter includes a compendious bibliography of its subject, which is essential for a review series of this kind. On this showing the whole series of (at least) four volumes will amount to impressive coverage of the whole field.

Nicholas G. Wrigley is at the Medical Research Council's National Institute for Medical Research, Mill Hill, London.

\section{A palpable hit}

\section{P.W. Hawkes}

Image Analysis and Mathematical Morphology. By J. Serra. Pp.610. ISBN 0-12-637240-3. (Academic: 1982.) $£ 48.40$, $\$ 99.50$.

THE appearance of this book is something of an event in the world of image analysis. For more than a decade now, scattered ideas and results have been emerging from the Ecole des Mines at Fontainebleau, suggesting that something new was in the air. A connected account was lacking, however, and even the individual publications were easily overlooked, many being internal reports and others published in a wide variety of serials. Such diversity is no accident: it reflects the broad range of possible applications of the methods but the absence of a single easily accessible text has meant that the ideas have been far too little appreciated, outside the Seine-etMarne at least.

With the publication of this fascinating and densely filled volume, there is no longer any excuse for ignorance of the methods. Not only is a coherent pattern imposed on the work of the Fontainebleau group and the necessary mathematical background sketched in but " 40 per cent of the material of this book has not been published before',

What then does Serra offer us? His text is divided into four large parts, on the mathematical tools needed, the role of partial knowledge (with chapters on digitalization and random sampling), the criteria applied in practical image analysis (covariance, size, connectivity and the study of half-tones) and finally the use of random models. All this is brought to bear on problems of image analysis in such a way that the results are in some welldefined sense independent of or insensitive to the exact choice of image (invariance under translation), its magnification, the incomplete nature of the information 